http://dx.doi.org/10.11646/phytotaxa.163.2.4

\title{
Typification of the plant names described by Nedeljko Košanin from the Balkan Peninsula
}

\author{
*SNEŽANA VUKOJIČIĆ, KSENIJA JAKOVLJEVIĆ, SANJA ĐUROVIĆ, NEVENA KUZMANOVIĆ, IVANA \\ JANKOVIĆ \& VLADIMIR STEVANOVIĆ \\ Institute of Botany and Botanical Garden Jevremovac, Faculty of Biology, University of Belgrade, Takovska 43, 11000 Belgrade, \\ Serbia \\ e-mail: sneza@bio.bg.ac.rs, kjakovljevic@bio.bg.ac.rs,sdjurovic@bio.bg.ac.rs,nkuzmanovic@bio.bg.ac.rs,ijankovic@bio.bg.ac.rs, \\ vstev@bio.bg.ac.rs
}

\begin{abstract}
Nedeljko Košanin was one of the most important Serbian botanists from the beginning of the 20th Century. He dedicated most of his life to investigate the flora of Southern Serbia as well as Albania and the Former Yugoslav Republic of Macedonia. Since he was working at the Institute of Botany and Botanical Garden in Belgrade, the majority of his collection is deposited in BEOU. While describing new taxa, in most of his publications he did not indicate the holotype. The present study discusses the lectotypification of 7 names published by Košanin alone, or with his contemporaries.
\end{abstract}

\section{Introduction}

Nedeljko Košanin (1874-1934) was an outstanding botanist with legacy of great importance in the fields of plant systematics, floristics and geobotany. His scientific work was particularly devoted to phytogeographic and floristic investigations of mountain ranges in FYR Macedonia (Mts Korab, Jakupica, Jablanica, Galičica, Nidže, Dudica, Kajmakčalan), Albania (Mts Jalica, Paštrik), SW \& S Serbia (Mt Golija, Region of Vlasina Plateau) (Janković \& Tatić 1984).

Košanin discovered and described a great number of taxa, alone or in colaboration with other botanists. Some of those taxa are Colchicum macedonicum Košanin (1911: 232), Crocus cvijici Košanin (1926: 23), Crocus scardicus Košanin (1926: 24), Dioscorea balcanica Košanin (1914: 37), Drosera macedonica Košanin (1922: 83), Ephedra macedonica Košanin (1926: 21), Narthecium scardicum Košanin (1913: 141), Salvia jurisicii Košanin (1926: 26), Sambucus ebulus var. deborensis Košanin (1930: 241), Centaurea candelabrum Hayek \& Košanin (in Hayek 1931: 746), Saxifraga coriophylla var. karadzicensis Degen \& Košanin (1911: 112), Verbascum macedonicum Košanin \& Murb (in Murbeck 1930: 220), Viola dukadjinica W. Becker \& Košanin (in Becker 1926: 145) and Viola raunsiensis W. Becker \& Košanin (in Becker 1928: 33). Given the fact that he worked at the Botanical Institute and the Botanical Garden of Belgrade University, the majority of his herbarium collection is deposited in BEOU (Thiers 2013, continuously updated).

In this paper the lectotypification of 7 names published by Nedeljko Košanin is discussed.

\section{Materials and methods}

Relevant literature has been consulted in order to find protologues for the new taxa described by Košanin. In addition to the herbarium material deposited in Herbarium of University of Belgrade (BEOU), we have also examined the material from the following herbaria: BEO, WU, W, K, B, P, BP. 


\section{Acknowledgements}

The study was supported by the Serbian Ministry of Education, Science and Technological Development (grant No. 173030).

\section{References}

Becker, W. (1926) Viola dukadjinica Becker et Košanin sp. nov. und Viola albanica $\times$ dukadjinica (V. Markgrafii W. Bckr. hybr. nov.). Repertorium specierum novarum regni vegetabilis 23: 145-146.

Becker, W. (1928) Violae novae balcanicae. Bulletin de l'Institute et du Jardin Botaniques de l'Université de Beograd 1: 33-35.

Degen, A. \& Košanin, N. (1911) Saxifraga coryophylla Gris. var. karadzicensis. Magyar Botanikai Lapok 10: 112.

Hayek, A. (1931) Prodromus Florae Peninsulae Balcanicae 2. Repertorium Specierum Novarum Regni Vegetabilis 30(2): 746.

Janković, M. \& Tatić, B. (1984) Profesor Nedeljko Košanin: in memoriam (povodom 50-to godišnjice smrti i 110-to godišnjice rođenja). Bulletin de l'Institute et du Jardin Botaniques de l'Université de Beograd 18: 1-6.

Košanin, N. (1911) Vegetacija planine Jakupice u Makedoniji. Glas Srpske Kraljevske Akademije 85: 184-242.

Košanin, N. (1913) Narthecium scardicum Košanin spec. nova. Österreichische botanische Zeitschrift 63: 141-143. http://dx.doi.org/10.1007/bf01650035

Košanin, N. (1914) Dioscorea balcanica Koš. n.sp. Österreichische botanische Zeitschrift 64: 37-39. http://dx.doi.org/10.1007/bf01644279

Košanin, N. (1922) Drosera macedonica spec. nova. Spomenica 83-85.

Košanin, N. (1926) Nove vrste u flori južne Srbije. Glas Srpske Kraljevske Akademije 119: 19-29.

Košanin, N. (1930) Sambucus ebulus L. var. deborensis Košanin. Bulletin de l'Institute et du Jardin Botaniques de l'Université de Beograd 1(3): 241-246.

McNeill, J., Barrie, F.R., Buck, W.R., Demoulin, V., Greuter, W., Hawksworth, D.L., Herendeen, P.S., Knapp, S., Marhold, K., Prado, J., Prud'Homme Van Reine, W.F., Smith, G.F., Wiersema, J.H. \& Turland, N.J. (2012) International Code of Nomenclature for algae, fungi, and plants (Melbourne Code) adopted by the Eighteenth International Botanical Congress Melbourne, Australia, July 2011 [Regnum Vegetabile 154]. Gantner, Ruggell, 240 pp.

Murbeck, S. (1930) Die in den Sammlungen der Universität zu Beograd enthltenen Jugoslavischen Verbascum-formen. Bulletin de l'Institute et du Jardin Botaniques de l'Université de Beograd 1: 220-222.

Stevanović, V. (1991) Horologija i taksonomski položaj Košaninovih taksona. In: Gajić, M. (ed.) Simpozijum "Nedeljko Košanin i botaničke nauke". SANU, Beograd-Ivanjica 289-306.

Stevanović, V. \& Niketić, M. (1990) Viola dukadjinica W. Becker \& Košanin a new species of the Yugoslav flora. Rasprave IV. Razreda SAZU 31(20): 317-326.

Thiers, B. (2013) Index Herbariorum: A global directory of public herbaria and associated staff. New York Botanical Garden's Virtual Herbarium. Available from: http://sweetgum.nybg.org/ih/ (accessed 23 March 2013) 